\title{
From Bootstraps to Hands-up: A Content Analysis of the Depiction of Poverty in Young Adult Literature
}

\author{
Crag Hill \\ University of Oklahoma \\ Janine J. Darragh \\ University of Idaho
}

"None of us got where we are solely by pulling ourselves up by our bootstraps. We got here because somebody-a parent, a teacher, an Ivy League crony or a few nuns-bent down and helped us pick up our boots." -Thurgood Marshall

Teacher-preparation programs provide the space for preservice teachers to navigate such social issues as, explicit instruction on race and ethnicity (Banks, CochranSmith, Moll, Richert, Zeichner, \& LePage, 2005; Gay, 2010; Pollock, Deckman, Mira, and Shalaby, 2010), gender and sexuality (Murphy and Ribarsky, 2013), and the social construction of adolescence (Petrone and Lewis, 2012; Petrone, Sarigianides, and Lewis, 2015; Saragianides, 2012). This instruction prepares future teachers to deal sensitively with these issues. In a study of 142 university teacher preparation programs, however, Jennings (2007) discovered that only $3 \%$ of secondary programs foregrounding diversity in their courses emphasized social class, far fewer than those programs that emphasized race/ethnicity, special needs, and language. Hughes (2010) argues "the role of education in combating poverty must focus not only on the curriculum and policies implemented in schools but also on teacher attitudes, beliefs, and classroom practices" (p. 57). Because English teachers continue to be drawn from a primarily white and middle class demographic (Hancock and Scherf, 2010), preservice teachers should try to gain greater awareness of how poverty affects students and communities. This article proposes that close study and discussion of young adult (YA) literature depicting poverty can be an effective medium to heighten awareness.

Our study investigated how YA literature portrays poverty and how these representations compare to lived experiences in the United States today. We used a qualitative critical multicultural content analysis to answer these research questions: 
1. In what ways does current YA literature (published after the Personal Responsibility and Work Opportunity Reconciliation Act of 1996) portray poverty?

2. How do those representations compare to current statistics regarding poverty in the United States?

3. What do these depictions mean for teachers of English?

\section{Literature Review}

According to the United States Department of Health and Human Services (2015), the poverty line for 2015 is $\$ 11,770$ for a single person and $\$ 24,250$ for a family of four. Although issues of poverty such as government support, homelessness, and welfare reform are in the headlines, reflecting Jenning's (2007) findings on the study of class in teacher preparation programs, research on the portrayals of poverty in YA literature was challenging to find (Chafel, Fitzgibbons, Cutter, \& Burke-Weiner, 1997; Darragh \& Hill, 2014). Searches of databases, including Academic Search Premier, JSTOR, ERIC, and Sage Journals, utilizing key words such as "poverty," "poor," "homeless," "young adult literature" and "adolescent literature" or combinations thereof, yielded only a handful of articles and one dissertation (Hill, 2011; Goodson, 2004; Vanderstaay, 1992) that focused solely on portrayals of poverty in YA novels and just a few more articles focusing on depictions of poverty in children's literature (Chafel, 1997; Chafel et al.,1997; Fitzgibbons \& Tilley, 1999; Jones, 2008; Kelley \& Darragh, 2011; Kelley, Rosenberger, \& Botelho, 2005; Lamme, 2000).

\section{Representations of Poverty in Contemporary YA}

Scholarship around the representations of poverty in YA literature is scant at best. Vanderstaay (1992) attempted to compose a YA novel based on oral histories of homeless Americans, but he found that "nonfiction accounts of teenage street life are not YA literature. Both genres describe initiation and coming-of-age stories, but YA novels assume a particular kind of coming-of-age story and a particular kind of narrator who must live within strict ethical and narrative boundaries" (p. 49). Echoing Bishop's (1990) notion of books as mirrors, windows, and sliding glass doors, Vanderstaay addressed the 
potential of YA literature to impact readers by saying that he wanted his students to know that there are people who have to grow up in a harsh world (homeless), but not that they have to. He wrote, "I want them to be compassionate and to learn to think for themselves to enter the adult world with their integrity intact... Life will teach them what 'is.' The fiction they read should flinch from none of this 'reality.' But it should also point to the possible, which is the purpose of YA literature" (p. 52). What adult authors say to adolescent readers can shape adolescents' identities and perceptions of others.

While it doesn't focus solely on poverty, Goodson's (2004) dissertation included socioeconomic status in the analysis of portrayals of diversity in YA literature. Goodson analyzed YA novels taken from the International Reading Association's Young Adult Choice books published from 1987-2003 to determine whether or not the protagonists in YA literature reflect our nation's diversity. She found that "results suggest the typical protagonists in contemporary young adult fiction are overwhelmingly upper/middle-class white girls who are linguistically intelligent" (p. 1). In her section specific to poverty, Goodson found that $13 \%$ of the novels she studied represented generational poverty (a family in poverty for at least two generations), and $6 \%$ featured situational poverty (a period of poverty caused by situational factors, such as environmental disasters, divorce, or severe health problems).

Finally, Hill (2011) looked specifically at representations of poverty in Wolff's (1993/2006, 2001, 2009) Make Lemonade trilogy, situating these depictions in comparison to Payne's (1996/2005) controversial poverty framework that has been the foundation of professional development in at least 35 states (Bomer, Dworin, May \& Semingson, 2008). Hill contends that this series both "reinforces and resists stereotypes about poverty" (p. 32) and that "Unless explicit classroom instruction is used in unpacking the depictions of poverty, using Make Lemonade in the classroom can do more harm than good" (p. 32). Though it specifically focuses on three texts, this article provides a starting point for analyzing depictions and perpetuations of stereotypes in other contemporary YA novels.

While search results were a bit more fruitful when extending the parameters to include depictions of poverty in children's literature, only a few articles that analyze representations of poverty in children's picture books were located, and these analyses 
revealed conflicting results. Chafel et al. (1997), Fitzgibbons and Tilley (1999), and Kelley and Darragh (2011) found the number of portrayals of poor white families in children's literature to be fairly aligned with data from the United States Census Bureau (2013), but Jones (2008) found an underrepresentation of poor white characters in children's books. These incongruous findings extended to other races: Chafel et al. (1997) and Fitzgibbons and Tilley (1999) determined that few children's books depict poor African Americans, and no children's books feature poor Asian Americans. Jones (2008), however, found an over-representation of African American characters, and Kelley and Darragh (2011) found a slight over-representation of Asian characters with socioeconomic challenges.

\section{Themes}

In addition to representations of poor characters in children's literature, scholars have analyzed recurring themes in these books. Among those identified are luck, invisibility, alienation, interdependence, resourcefulness, resiliency and activism; (Kelley, Rosenberger, and Botelho, 2005; Lamme, 2000; Kelley \& Darragh, 2011), homelessness and violence (Fitzgibbons and Tilley, 1999); and unemployment, setting, and education (Chafel, Fitzgibbons, Cutter, and Burke-Weiner, 1997). Again, the lack of scholarship on this topic, as well as how these themes may manifest themselves differently in YA versus children's literature, make it difficult to draw conclusions about recurring theme development in YA literature that portrays poverty. The categories we measured in our data analysis (see below) roughly map onto these themes, particularly interdependence, resourcefulness, resiliency, and activism, as we tabulated the kinds of actions and the agents of these actions depicted in the novels.

\section{Voices Heard, Voices Silenced}

Historically, issues of class in general and poverty in particular have not been fully discussed when talking about diversity (Jennings, 2007). Botelho and Rudman (2009) used Ortner's (1991) work in anthropology to explain this phenomenon: "Anthropological research, like other social science inquiry, tends to overlook class because it is a layer of reality that we do not talk about. The American Dream ideology 
contributes to this silence in public and academic discourse...The U.S. ideology around social mobility masks class, racial, and gender inequities, placing the blame of economic oppression on the individual" (p. 89). Botelho and Rudman cite a lack of research analyzing portrayals of class in children's literature, emphasizing that the dominant (e.g., white, middle class, capitalistic) perspective may "construct a false universality of experience, masking the difference in participation and insight among other groups" (p. 91).

There is also some conflict in the literature regarding whose poverty story is being told and how this story compares to the lived experiences in our nation. For example, in their analysis of children's picture books that portray poverty, Kelley and Darragh (2011) found an absence of depictions of both American Indians and contemporary rural poverty settings. In addition, Goodman (1985), Overstreet (2001), Kelley et al. (2005), and Kelley and Darragh (2011) all found a dearth of discussion regarding hegemonic economic structures and social institutions; the lack of systemic action coordinated across local, state, and national contexts; and how these forces can contribute to the entrenchment of generational poverty. Few picture books or YA novels implicate poor schools staffed with the least qualified teachers, limited access to affordable health care and nutritious foods, and other risk factors that may keep people mired in poverty (Comber, 2015). In analyzing the Make Lemonade trilogy, Hill's (2011) article offers an in-depth discussion of these factors, noting stereotypes that can be perpetuated when implementing Payne's (1996/2005) professional development program concerning poverty without caution, but at the time of this writing, no other articles could be found on this topic.

While a variety of factors may contribute to these inconsistencies in analysis of representation, including the race of the author and his/her choice of protagonist, the lack of scholarship in this area rather than the conflicting data results proves most concerning. This study attempts not only to add to the existing literature but also to compare the results to the current demographics and provide an entry point of discussion for English educators tasked with preparing preservice teachers to work with students experiencing poverty. 


\section{Theoretical Framework}

Critical sociocultural theory (Lewis, Enciso, \& Moje, 2007; Vygotsky, 1993) and reader response theory (Beach, 1993; Probst, 2004; Rosenblatt, 1938/1999/2005) provide the framework for this study. Operating under the position that literature as taught in secondary schools is a mirror and window for understanding self and others, Bishop (1990) theorizes that cultural background and experiences, lived or learned through written and spoken word, can impact how one views and responds to others of different backgrounds or experiences. Because YA literature in the last 15 years has attained a prominent position inside and outside the classroom, through print and film adaptations, and reflects the concerns and struggles of the next generation, we decided to use this body of literature as a barometer of the cultural conversation on poverty. Written by adults who want to tell stories to adolescent readers (to teach, to inculcate), YA literature is a rich nexus within which to measure the transmission of cultural messages from adult writers to adolescent readers, from the present to the future. Messages about poverty are complex and difficult to measure across the cultural spectrum; both implicit and explicit depictions of poverty in YA literature are also complex and difficult to unpack. This study provides one method to quantify what this body of literature may be conveying to its readers.

We concur with Enciso's (2007) belief that "For sociocultural theorists and educators it is crucial to the direction and substance of our work that we question what narratives are available and how they become available in dialogue with present resources among members of ideologically and historically diverse groups" (p. 57). YA novels that portray poverty can give voice to an often silenced and underrepresented group, and how readers respond to these novels can impact their interactions with and beliefs about themselves and others. In utilizing a critical multicultural qualitative content analysis (Botelho and Rudman, 2009) within a sociocultural framework, representations and identities can be identified in both individual books and in the data set as a whole. Issues revolving around potential stereotypes can be unearthed as well as what an overrepresentation and/or an under- or lack of representation can mean to readers. 


\section{Methods}

Employing a critical multicultural qualitative content analysis (Botelho \& Rudman, 2009), modeled after a study of children's picture books (Kelley \& Darragh, 2011), this study analyzed YA novels that portray living in poverty after 1996's Personal Responsibility and Work Opportunity Reconciliation Act (PRWORA), a major piece of welfare reform. Botelho and Rudman (2009) explain that critical analysis "is a frame for teaching literature and constructing curriculum and spaces to take up issues of diversity and social injustice by problematizing children's literature" (p. xv). The method guides teachers to identify the ideological implications in studying literature. Botelho and Rudman (2009) argue that in "uncovering systems of meaning that perpetuate social inequities, readers can reposition themselves in the world and envision new intellectual spaces, breaking ground for constructing new social worlds" (p. xv). Kelly and Darragh (2011) used this critical multicultural content analysis to investigate discourses of poverty in realistic children's picture books, and we decided to apply their methodology to a corpus of YA novels. In our study we sought to identify and document ideological assumptions present in these novels, as well as how the representations in YA fiction compare to those in children's picture books about poverty.

Our initial data collection consisted of identifying the following categories in each of the 71 YA novels published between 1996 and 2013: main character, geographic locale and time era; age, gender, race of focal character experiencing poverty; which character takes action in response to the impoverished conditions; what type of action is exercised, e.g. individual (character moves to a new neighborhood), family/friends (character receives help from friends/family in the form of shelter, money, or in securing employment), community (character receives help from a school or a church or a local charity), systemic (character receives cash-assistance, food stamps, health care, job training and job placement). The latter category was of primary interest. In identifying which characters take action and identifying the type of action, we believed we would uncover the authors' ideological messages, whether implicit or explicit, about poverty. Kelley and Darragh (2011) found that only 3.5\% of children's books displayed action at the systemic level (p. 276), so we also were interested in determining whether adult writers for young adult readers pointed their characters toward becoming aware of and 
utilizing institutional resources available to them.

\section{Book Selections}

We conducted a comprehensive search to identify post-PRWORA YA novels that have poverty as a central theme. Using combinations of the search terms poverty, poor, homelessness, YA, teen, adolescent fiction, we searched the library catalogue through World Cat, amazon.com, and barnesandnoble.com, and we also sought recommendations from librarians and YA literature scholars. For the purpose of this study we adhered to Stephens (2007) definition of YA literature as "a story that tackles the difficult, and oftentimes adult, issues that arise during an adolescent's journey toward identity" (p. 40). We identified and analyzed 71 YA novels that met the following criteria: 1) realistic fiction set and published between 1996 and 2013 (quite a number of novels written in that time span were set in historical periods such as the Great Depression; though these novels would also reflect the conversations around poverty, they took place when government systems were markedly different and could not be easily compared to novels set in the contemporary era); 2) protagonists between the ages of twelve and eighteen (with one exception, a nineteen year old protagonist); 3) poverty as a central theme; and 4) set in the United States.

\section{Data Coding}

At the project's outset, both authors read a convenience sample of eight novels that depict poverty and completed a data collection chart to ensure that the data coding would have inter-rater reliability. We met and compared our codings, which matched in all cases. We then identified 71 young adult novels that met our criteria and documented the following information: (a) author and title; (b) whether the main character was poor; (c) time era and geographical locale, rural or urban; (d) age, gender and race of the poor character(s); (e) character who demonstrates action; and (f) type of action taken, whether the action was individual, family/friends, community, or systemic. We divided the reading by convenience (who had easier access to the book), read the books, and filled out a shared chart upon finishing reading. As the study progressed and we discussed our initial categories, we added new categories to document the incidences of violence, mental 
illness, and teen pregnancy, issues that were appearing in the novels with notable frequency. Once all books had been read and coded, we performed descriptive statistics on each category that we then compared to information from the U.S. Census Bureau. A selection of books that we felt could be particularly useful for teachers of English (based on our combined 46 years of teaching secondary English and English education courses) was identified and discussed in depth (see below).

\section{Results}

The majority of the novels, $84.5 \%$, took place in the $2000 \mathrm{~s}, 12.7 \%$ in the $1990 \mathrm{~s}$, and $2.8 \%$ of the novels failed to indicate the time period, though they depicted situations and characteristics that could have indicated a modern setting

In $81.9 \%$ of the books, the focal poor character was the protagonist, with $9.7 \%$ having another poor character besides the protagonist, and $8.3 \%$ of the books having multiple protagonists who are poor including the focal poor character.

The age of the poor focal character in all books ranged from 3-23 years. Many of the books had either multiple characters of different ages and/or spanned several years in a character's life. The most common age for a focal poor character was 16 . In addition, there was an almost even representation of gender of the focal poor character who was poor, with $42.3 \%$ male protagonists, $47.9 \%$ female protagonists, and $9.9 \%$ of the books having multiple protagonists including both male and female characters.

In tracking the race/ethnicity of the protagonist, 53.5\% were white, $19.7 \%$ were African American, 8.5\% were Hispanic, 8.5\% were biracial, 5.6\% were undetermined, $1.4 \%$ were Native American, and 2.8\% had multiple protagonists of different races. Two novels featured more than one protagonist, and these multiple protagonists were of different races/ethnicities. We counted each protagonist separately for each race/ethnicity that he/she represented. Because the protagonist was often the focal character who is poor, the following numbers were similar. $50.7 \%$ of the focal poor characters were white, 21.1\% were African American, 11.3\% were biracial, 7.0\% were Hispanic, 5.6\% were undetermined, 1.4\% were Native American, and 0\% were Asian.

Arriving at different results to studies of children's literature (Chafel et al., 1997; Fitzgibbons and Tilley, 1999; Jones, 2008; and Kelley and Darragh, 2011), with regards 
to race, we found an overrepresentation of white, non-Hispanic characters living in poverty in the novels we read, as well as an underrepresentation of every other group, with characters who are Asian not being represented at all (see Appendix A). For example, white, non-Hispanic characters constituted $50.7 \%$ of those in poverty compared to $12.4 \%$ in the population according to the United States Census Bureau (2013). African Americans, who currently constitute $25.8 \%$ of people in poverty, were slightly underrepresented (21.1\%), but the largest group of people in poverty, American Indians and Alaska Natives (27\%), were rarely depicted (in $1.4 \%$ of the books surveyed). This overand underrepresentation of the race of people in poverty may seem counterintuitive, as news media frequently depict poor African Americans negatively and inaccurately (Gilens, 2009). Though this overrepresentation of poor white characters may be attributable to most of the authors being white, this overrepresentation is still problematic, as overrepresentations may "construct a false universality of experience, masking the difference in participation and insight among other groups" (Rudman and Bothelo, 2009, p. 91).

Of the books surveyed, $63.4 \%$, took place in an urban/large city setting, while $12.7 \%$ took place in a rural setting. In addition, $8.5 \%$ of the books took place in a suburb, $8.5 \%$ in a small town, and $7.0 \%$ in multiple settings. Of the 71 books analyzed, $28.2 \%$ took place in New York City, and $14.0 \%$ took place in California. Similar to Kelley and Darragh's (2011) results from analyzing portrayals of poverty in picture books, our study found a clear overrepresentation of urban poverty and an underrepresentation of the rural poor. While only $12.7 \%$ of the novels we analyzed portrayed rural poverty, the reality is that the percentage of people living in poverty is nearly equal in rural and urban areas. In $2010,22.3 \%$ of people in rural areas lived below the poverty line. This statistic compares to $24.4 \%$ of people living in urban areas and $14.0 \%$ of people living in suburban/exurban areas (Housing Assistance Council, 2012). Moreover, according to current statistics from the Rural Poverty Research Institute (2013):

Over 7 million people still live in poverty in rural areas, and poverty is deep and persistent in several regions of our nation...Poverty rates are higher and more persistent in nonmetropolitan than in metropolitan areas. Along a continuum of 
the most urban county to the most rural county, poverty rates are highest in the most remote rural areas.

In our analysis, we found not only an underrepresentation of rural and suburban poverty but also an overrepresentation of two states: New York and California. Of the forty-five novels that have urban settings, twenty (44.4\%) take place in New York (e.g., the Bronx, Brooklyn, Harlem, etc.), and ten $(22.2 \%)$ in California. A supplemental survey to the 2010 U.S. Census provided information on the percentage of children who live in poverty in each state. These data were compared to the portrayals we found in the young adult novels. In both New York and California, 23\% of children live in poverty, but other states suffer from even higher child poverty rates. While depictions of high-poverty settings such as New Mexico, Arizona, South Dakota, and Mississippi are seemingly absent from this body of work, the overrepresentation of urban poverty might be sending unintended messages about where poverty abounds in the United States. Similarly, for teens who live in rural poverty, the absence of depictions denies them the chance to connect with characters like themselves, to feel validated and as though their stories are worth telling.

There was an overrepresentation of teen pregnancy, with $35.2 \%$ of the novels containing teen pregnancy, whether it was the protagonist, his partner, or his or her mother, sister, or friend who was or had been a teen mom. This large number of teen mothers in the novels differs from the current statistic of $2.7 \%$ of teens giving birth in 2013 (CDC, 2015). In fact, the reality is that teen births have hit an all-time low in the United States. Between 1990 and 2008, the teen pregnancy rate declined by 42 percentfrom 116.9 to 67.8 pregnancies per 1,000 teen girls, and there was a decline of $8 \%$ from 2010 to 2011 and another 10\% drop from 2011 to 2012. Moreover, the majority (71\%) of teen births are from 18-19 year-olds (U.S. Department of Health and Human Services, 2013). Though the number of teen mothers is dropping, those who are teen moms are more likely to struggle financially and are much more likely to need support from the government (March of Dimes, 2012; Why it matters, 2010). For example, more than three quarters of all single teenage mothers receive welfare services in the first five years of their children's lives. Dropping out of high school seems to exacerbate the situation, as children of single, dropout teenaged mothers are almost ten times more likely to live 
below the poverty line than children whose mothers are over the age of twenty, married, and high school graduates (March of Dimes, 2012). While teen pregnancy certainly contributes to financial struggles, these financial struggles are not as pervasive as this collection of novels suggests.

Geographic location also proved significant: states with the highest rates of teen births also had the highest rates of child poverty. (Annie E. Casey Foundation, 2013; U.S. Department of Health and Human Services, 2013). However, in the novels we read, the incidences of teen motherhood, again, occurred mostly in urban areas, specifically in New York. Of the 25 books that display teen motherhood, 92\% take place in an urban setting, with $40.0 \%$ taking place in New York, and $12.0 \%$ taking place in California. Collectively, the novels we studied convey the message that poverty and teen pregnancy are seemingly rampant in certain geographic locales.

Though we started the project utilizing the same categories used in Kelley and Darragh's (2011) study of children's literature, we also identified and tracked patterns specific to YA literature. Violence and/or crime were portrayed in the $84.5 \%$, of the novels. Moreover, of 20 novels that took place in New York, 90\% portrayed violence and/or crime, and of the 10 novels that took place in California, 90\% portrayed violent and/ or criminal activity. Conversely, only $54.2 \%$ with rural settings depicted violent and/or criminal acts. While statistics show a correlation between lack of income and crime, other factors such as unemployment and education level correlate, exacerbate, and complicate this issue (Crime and Poverty, 2014; Plummer, 2010). Having so many $(84.5 \%)$ of the novels, particularly novels set in New York City (90\%), portray violence and crime may contribute to existing negative stereotypes about poor people in urban locations.

Additionally, $52.1 \%$ of the books portrayed a character with some sort of mental health challenge, such as depression (37.8\%), drug addiction (37.8\%), alcoholism (16.2\%), schizophrenia and bi-polar disorder (5.4\%). Other mental health issues depicted include obsessive-compulsive disorder, mental retardation, self-mutilation, anorexia, attention-deficit disorder, dementia, general mental illness, and fetal drug syndrome. We looked specifically at the books that portrayed mental illness and identified which character had the mental challenge: in $40.5 \%$ of these books, the mother had the mental 
challenge; in $27.0 \%$, the protagonist; in $16.3 \%$, multiple characters; in $8.1 \%$, the father; and in one notable depiction $(2.7 \%),=a$ brother, sister, and grandmother . With regards to representations of mental health challenges, the novels appear to accurately represent the fact that in the United States today, those who struggle with mental illness are more likely to also struggle financially Numerous studies have found a correlation between mental health and poverty (Bassuk, Buckner, Perloff, \& Bassuk, 1998; Belle \& Doucet, 2003; Bogard, Trillo, Schwartz, \& Gerstel, 2001; Brown \& Moran, 1997; Bruce, Takeuchi, \& Leaf, 1991; Gyamfi, Brooks-Gunn, \& Jackson, 2001; Hudson, 2005). However, the novels may perpetrate or perpetuate gender stereotypes of which students and teachers need to be cognizant. The mother was the character with the mental health challenge in $40.5 \%$ of the books, almost five times the $8.1 \%$ of novels that portrayed the father as struggling with mental illness.

Finally, in $95.8 \%$ of the novels, some type of action was displayed. $9.9 \%$ of the books showed just individual action, or the poor character him- or herself trying to overcome financial hardship. $85.9 \%$ of the books displayed multiple forms of action (individual, family/friends, community, and/or systemic). Over half the novels made no mention of local, state, or government services, and less than $20 \%$ of the novels depicted residency in foster homes, group homes, shelters, or other housing. In some of the novels that did mention government and community support, these resources did not allay but actually contributed to the poor character's discomfort and suffering. While some of the novels sent a message or even contained resources for ways to find and get help, just as many of the books demonstrated that this type of "help" was harmful—abuse and neglect happened in foster homes, violence was rampant in shelters, if one was lucky enough to find space in one. In over half of the novels, teenagers in poverty lived below the radar, not even receiving information about possible services such as free and reduced lunch at school, transitional living accommodations, free childcare, free employment training and schooling, and transportation waivers.

In short, the typical book in our study had a focal poor character who was white, 16 years of age - characters were split between genders - living in an urban setting, most commonly New York. In almost all of the books, the character acted to change his/her circumstances, or he/she was the benefactor of others' actions. The character was a 
member of a single-parent family and who may have had a child of his/her own; was likely the perpetrator, victim, or witness of violence; and was likely to be suffering from or witness to depression, drug addiction, and/or alcoholism (see Appendix B for full list of books).

\section{Discussion and Implications: What does this mean for teachers of English?}

Poverty is not a cultural construct. It has pernicious structural causes and consequences for individuals, states, and the nation as a whole (Gorski, 2008). Deliberate actions by individuals in power held in a nexus of government and economic entities have arguably institutionalized poverty (Giroux, 2014). Policy makers, news media, and others have foisted negative stories on the populace, but even more damaging are the efforts to build impermeable, impenetrable barriers between individuals who have and who lack housing, access to quality food, health care, and adequate transportation-those who fill both our and our students' future classrooms and try to learn and overcome despite the odds stacked against them

In brief, we were heartened to find in the 71 YA novels we analyzed that there was not an overwhelming fostering of stereotypes regarding people in poverty. If we were to narrow our study to one overarching finding, we might say that this group of novels conveys a "pull yourself up by your bootstraps" ethos with a twist: it is the teens' responsibility to lift themselves out of poverty, yet they need not, and perhaps cannot, do it alone. Teens need other people to help lift them up, to support them as they are tugging on those proverbial bootstraps, and to provide them another pair of straps if theirs fall apart. Teens who are socioeconomically challenged must seek out and utilize the resources they have available to them at school. They must seek out and utilize the food and housing resources in their community as needed, even if those resources may put them in potentially dangerous situations. As teachers may be the first adults in whom students confide, teachers must be a conduit to the school and community resources that can help students during rough times.

These novels have shown overwhelmingly that multiple factors contribute to poverty both in the short- and long-term. Because there are multiple factors, possible solutions must be multi-pronged and designed to change the societal conditions of 
poverty and address the needs of individuals. There will be no easy solution, no stroke of the pen, no single legislation that will reduce the incidence of poverty in the foreseeable future. Like many of the characters in the novels we studied, we must as a country dig in, never give up, and look not only to our own strengths but to others' strengths to identify the many causes of poverty. Individual anecdotes about men and women who have become enormously successful in spite of childhoods riddled with poverty may make us feel good, but those success stories are exceedingly rare. Teens and teachers of teens need a variety of stories from which to draw ideas, encouragement, and strength.

As with the study of children's picture books (Kelley \& Darragh, 2011), very few of the novels in our study explicated the systemic roots of poverty. Therefore, we make the recommendation that teachers using YA literature do not simply take a book at face value. A novel such as Coe Booth's (2007) Tyrell may on the surface depict poverty in ways that perpetuate harmful assumptions about poor people. For example, Tyrell's mother represents - or, rather, misrepresents - people in poverty as lazy, untrustworthy, prone to violence, and concerned with instant gratification. These individuals are not given a hand to help pull themselves up; they are expected to lift themselves up by their sheer initiative. But what if they don't have anything on which to stand? How do these students start to better their situations? When studying novels depicting poverty, those questions need to be carefully discussed. These books need to be contextualized, and the teacher preparation classroom is an ideal place to start that contextualization.

To help our students look at poverty more critically, we recommend instructors obtain novels that offer multifaceted portrayals of poverty and engage students in discussions on the complexity of poverty by using some of the novels we suggest. For teacher -education programs, we recommend continuing to unpack the complexity of poverty in all courses. Poverty has serious academic consequences. Chronically hungry students have difficulty concentrating in class, completing work out of class (many without study space in their homes or access to computers), and their attendance may be adversely affected (Jensen, 2009). Preservice teachers must be equipped to work with students who are socioeconomically challenged.

We are well aware, however, that when our students, future English educators, enter their own classrooms they will have great influence on their students, and they must 
wield that influence judiciously. YA literature about poverty should be included in their classrooms because it contributes to the conversations about diversity, particularly around class. Students who struggle financially deserve to see their lived experiences represented in the curriculum. Students who are not struggling need to know that their experience is not necessarily the economic experience of their peers. Students living in the city need to know that rural poverty exists, and all need to know that while financial struggles can make life more difficult, they do not make life hopeless. We must also train our English education students to be advocates for the use of YA literature across disciplines in their schools. In history and government classes, YA literature that portrays poverty can be used to look at class issues throughout the ages and with attention to policy and national economics. A science class or health class can use these novels as case study discussion points on environmental and health-related issues that are exacerbated by living in need. The possibilities are endless.

In all cases, however, instructors of YA literature and Secondary English Methods courses must pay close attention to what is said and not said in these novels and help their students acquire not only critical reading but also critical thinking skills. If students read YA literature and other media depicting poverty and do not use a critical eye, the stereotypes perpetuated in our culture could persist for many more generations. As the research suggests, we have heretofore been seemingly reluctant to bring issues of poverty, of class, into our teacher preparation programs. But to leave class as it is commonly and even erroneously represented in the literature our students - and their students - read is a grave disservice. We must prepare our students, the future teachers of English, to recognize when our assumptions add to a problem.

In this study we found that the depiction of poverty in YA novels published after PRWORA was complex and that the often divisive debates on poverty that occur in the public arena, therefore often spilling over into our teacher preparation classes, may miss the subtlety that a narrative may convey. Fictional stories about families and individuals in poverty may paint a more authentic picture of the multiple factors that contribute to living in poverty than statistics and news stories can capture. In the following section, we discuss a sample of novels that cut across the patterns we identified: novels that promulgated many of the stereotypes around poverty and/or offered unrealistic solutions 
for escaping poverty to its protagonists and novels that problematized those stereotypes, undercutting many of them. These exemplar texts may be useful for current and future teachers of English to read and analyze as a vehicle to reflect upon their personal assumptions regarding poverty, as much as they may be useful for use in a classroom with their own students. Moreover, the examples may be used to generate discussion on this complex issue at a variety of levels - for middle and high school students and the teachers of these students as well as for pre-service teachers and university students studying YA literature, offering a basis for making novel selections in classroom units studying poverty.

Novels promulgating stereotypes/Unlikely solutions

Several novels dressed characters in stereotypes without offering other, perhaps redeeming, characteristics or painted characters with nuance, but then sprung an unrealistic, contrived ending on the reader. These novels may tell good stories, but they do not provide authentic models for teen readers who may be experiencing some of these issues. However, such problematic novels can still initiate discussion in classrooms. Provided that teachers can have follow-up discussions with students who read these novels independently, to talk about the endings, we would recommend them. Following are two novels we found particularly problematic.

\section{Chill Wind}

In Janet McDonald's (2002) Chill Wind, 19-year-old Aisha "could be the poster child for those who blame the individual for their economic circumstances" (Darragh \& Hill, 2014, p. 79). She wears the negative stereotypes about women who are poor like badges of honor. She has two babies (the first when she was 15), enjoys the federal assistance she has been given for five years (it enables her "chill" existence), does not possess a high school diploma, and refuses the workfare job she is assigned when her benefits have expired. To the novel's credit, her mother, her friends, and other authorities criticize her lazy behavior; in fact, a nurse rebukes her when she tries to further her government assistance by feigning mental illness. With no benefits, she must look for a job. Uneducated and unskilled, Aisha does not qualify for many jobs, but when she answers 
an ad for Big Models she finds a determination heretofore missing from her life. Initially rejected, Aisha insists that she can be a successful model and eventually wins over the agency. She becomes a star model and begins to earn a fortune in what according to an article on collegetimes.com is one of the "11 hardest jobs in America to land." Aisha's newfound resolve is a noteworthy trait for readers to aspire to, but her unlikely success may encourage readers "to focus on unattainable rather than realistic goals" (Darragh \& Hill, 2014, p. 81).

Skate

Michael Harmon's (2008) Skate follows a pattern common to many YA novels, including those depicting poverty: absent parents and clueless school authorities. Such a volatile combination means the teenaged protagonist is forced to take on the role of adult and/or parent. In this novel, Ian's mother is addicted to drugs and alcohol. Ian is determined to take care of Sammy, his younger brother who struggles from fetal alcohol syndrome, finding food and shelter for him when his mom is using and/or prostituting herself for drugs. Afraid that he may lose Sammy to Child Protective Services after he was involved in a violent incident with a teacher at school, Ian decides to run away from home to find the father they have never met. What ensues is a road trip of unexpected kindnesses and near misses with the law from Spokane, Washington to the Washington State Penitentiary in Walla Walla, Washington where the boys find out that their father is not an inmate but the warden of the institution. The father uses his power to ease the consequences for Ian's actions, and he decides to take custody of Sammy. In this case the system works expeditiously for Ian and Sammy, but it might not have moved so quickly had they not had a powerful father in a position of authority. In most cases, even if the boys were able to engage an absent father, Ian and Sammy would likely continue to have difficulties ahead of them, all of which would need the help of individuals and government services.

Novels problematizing/undercutting stereotypes

Many of the YA novels we studied authentically represented the complexity and 
struggles of poverty. At the very least, these novels neither condemned the individual nor held institutions/government solely responsible for an individual's economic state. Below are three examples of novels we feel would be particularly effective for spurring discussions regarding the complexity of and multiplicity of factors contributing to poverty, not only in an English classroom, but also in social studies and health classrooms.

\section{A Room on Lorelei Street}

In Mary Pearson's (2005) A Room on Lorelei Street, seventeen-year-old Zoe, weary from caring for herself, her brother, and their unemployed, alcoholic mother, decides to leave her mother's house. Zoe rents an apartment from Opal Keats, an eccentric, optimistic older woman. Zoe, a conscientious girl, maintains a job, completes schoolwork, participates in sports, and adheres to a strict budget. But ultimately, she cannot work enough hours to pay the rent, feed herself, and afford gas. Desperate to remain living on her own, she sleeps with a man for money but is haunted by the action. After contemplating suicide, Zoe decides to leave town, to live with an aunt and to try again to make a living. This novel exemplifies the harsh reality of living on one's own without the wages and benefits of a full-time job paying more than minimum wage. Zoe's heroic if sometimes desperate individual effort alone is not enough to gain her a solid economic footing.

\section{Shelter}

Only the rare YA novel doesn't demonize homeless shelters. Rather, Beth Cooley's (2006) Shelter depicts temporary housing as an important parachute for those free-falling through their lives. For Lucy, her mother, and her brother Jimmy, the homeless shelter is a place where the family can hit bottom, regain their bearings, and begin to recover. Lucy's father has recently died, and his death revealed that their affluent life in the suburbs was not as it seemed. The family was burdened with debt, with no life insurance or other means to pay the bills. Her mother, a stay-at-home mom with no work experience, plummets into despair. Jimmy adapts to the shelter quickly and finds a group 
of friends, but Lucy and her mother struggle with their new circumstances. Their lives begin to change when they stop viewing the residents of the shelter-and their own lives - through a middle-class lens and begin to see how people persevere, how they seek out and accept the support the shelter and the city offers people in their circumstances, such as GED classes and other job training. Though the ending may be too cliché or contrived-Lucy's mother has a job she can be proud of, meets a man she can trust and respect - the setting of the novel rings true. The characters, for a change, have not "earned" their dire circumstances through self-destructive behaviors, but instead they represent those individuals and families who may contend with situational poverty.

\section{Crossing the Wire}

Similar to American citizens in poverty, undocumented immigrants are often accused of being a drain on government resources, taking but not giving back through taxes. (American Civil Liberties Union, 2008). Will Hobbs' (2007) Crossing the Wire, however, puts a human face on the immigration debate. Fifteen-year-old Victor Flores, like many immigrants, does not want to be a problem; he just wants to feed his family, his recently widowed mother and four siblings. The Flores family and other families in the area have long made a living growing corn and other crops, but subsidies given to American farmers have left Mexican farmers unable to compete with the price of corn exported to Mexico. The price bottoms out, and it is not even worth planting a crop. Like many men in his village, his only option is to try to find work in El Norte. Without papers, unable to afford the coyotes who smuggle illegal workers across the border, Victor attempts the dangerous trip on his own, but he is caught and sent back to Mexico. His family now on the verge of starving, Victor takes desperate measures by joining a group of smugglers packing drugs into the United States. From a comfortable distance, one may fault Victor's choices, but there aren't any other choices to make. His family has no income or savings to pay for food, there are no available jobs in the village or in nearby cities for Victor, no government safety net for him and his family while they search for gainful employment. Survival of the family blurs the lines between right and wrong. 


\section{Conclusion}

In this study we sought to determine how current YA literature (published after the Personal Responsibility and Work Opportunity Reconciliation Act of 1996) portrays poverty, how those representations compare to current statistics regarding poverty in the United States, and what those depictions mean for teachers of English. We found that regardless of representations, accurate or otherwise, teachers can use these texts to discuss poverty and financial insecurity with their students. As such, we must make space in all our English education classes to raise the quality of discourse around poverty. Only then can we ask our pre-service and in-service teachers to take action to ameliorate the effects of poverty on our students.

Given the current financial climate in the United States, coupled with the exorbitant number of children and young adults living below the poverty line, teachers and teacher educators must gain awareness of the hidden messages of their curriculum and pedagogy (Haberman, 1991/2010). As the classroom is but one site for action, teachers and other school professionals must help students in poverty to identify what they need to improve their economic circumstances and what supports are available to them. To begin to break the cycles of poverty some families experience, we must work to remove the stigmas on the resources available.

Poverty is a circumstance that can be changed, not something to cause shame. When the literature we ask students to study reifies stereotypes about poverty, breaking down those stereotypes must be a critical part of the work done in the classroom. Such study will begin to provide students - and teachers-with the language to talk about poverty and other class issues in productive rather than accusatory terms. That is one bootstrap we can give all our students. 


\section{References}

American Civil Liberties Union (2008). Retrieved from:

https://www.aclu.org/immigration-myths-and-facts

Annie E. Casey Foundation. (2013). Kids Count Data Center. Retrieved from: http://datacenter.kidscount.org/data/tables/43-children-in-poverty\#detailed/2/1019,2,20-29,3,30-39,4,40-49,5,50-52,6-9/false/867/any/321,322

Banks, J., Cochran-Smith, M., Moll, L., Richert, A., Zeichner, K., LePage, P., DarlingHammond, L., \& Duffy, H. with McDonald, M. (2005). Teaching diverse learners. In L. Darling-Hammond \& J. Bransford (Eds.), Preparing teachers for a changing world: What teachers should learn and be able to do (pp. 232-274). San Francisco: Jossey-Bass.

Bassuk, E.L., Buckner, J.C., Perloff, J.N., \& Bassuk, S.S. (1998). Prevalence of mental health and substance use disorders among homeless and low-income housed mothers. American Journal of Psychiatry, 155(11), 1561-1564.

Beach, R. (1993). A teacher's introduction to reader-response theories. Urbana, IL: National Council of the Teachers of English.

Belle, D., \& Doucet, J. (2003). Poverty, inequality, and discrimination as sources of depression among U.S. women. Psychology of Women Quarterly, 27, 101-113.

Bishop, R. S. (1990). Mirrors, windows, and sliding glass doors. Perspectives: Choosing and using books for the classroom, 6(3), ix-xi

Bogard, C.J., Trillo, A., Schwartz, M., \& Gerstel, N. (2001). Future employment among homeless single mothers: The effects of full-time work experience and depressive symptomatology. Women and Health, 32(1-2), 137-157.

Bomer, R., Dworin, J. May, L. \& Semingson, P. (2008). Miseducating teachers about the poor: A critical analysis of Ruby Payne's claims about poverty. Teachers College Record, 110(12), 2497-2531.

Booth, C. (2007). Tyrell. New York: Scholastic.

Botelho, M.J., \& Rudman, M.K. (2009). Critical multicultural analysis of children's literature: Mirrors, windows, and doors. NY: Routledge.

Brown, G.W., \& Moran, P.M. (1997). Single mothers, poverty and depression. Psychological Medicine, 27, 21-33. 
Bruce, M.L., Takeuchi, D.T., \& Leaf, P.J. (1991). Poverty and psychiatric status. Archives of General Psychiatry, 48, 470-474.

Center for American Progress. (2013). The straight facts on women in poverty. Retrieved from: http://www.americanprogress.org/issues/women/report/2008/10/08/5103/thestraight-facts-on-women-in-poverty/

CDC: Centers for Disease Control and Prevention. (2015). Reproductive Health: Teen Pregnancy. Retrieved from: http://www.cdc.gov/teenpregnancy/about/index.htm

Chafel, J. A. (1997). Children's views of poverty: A review of research and implications for teaching. The Educational Forum, 61, 360-371.

Chafel, J. A., Fitzgibbons, S. A., Cutter, L., \& Burke-Weiner, K. (1997). Poverty in books for young children: A content analysis. Early Child Development and Care, 139, 13-27.

College Times. (18 November, 2009). 11 hardest jobs to get in America. Retrieved from: http://www.collegetimes.tv/11-hardest-jobs-to-get-inAmerica/

Comber, B. (2015). Critical literacy and social justice. Journal of Adolescent and Adult Literacy, 58, 362-367.

Conger, R.D., Conger, K.J., \& Elder, G.H. (1997). Family economic hardship and adolescent adjustment: Mediating and moderating processes. In G. Duncan \& J. Brooks-Gunn (Eds), Consequences of growing up poor. New York: Russell Sage Foundation.

Cooley, B. (2006). Shelter. New York: Random House.

Crime and Poverty Statistics. (2014). Retrieved from: http://www.streetdirectory.com/etoday/crime-and-poverty-statistics-faopl.html

Darragh, J. J. \& Hill, C. (2014). 'The Worst Form of Violence': Unpacking Portrayals of Poverty in Young Adult Novels. In Hill, C. (Ed.). The Critical Merits of Young Adult Literature: Coming of Age. New York: Routledge.

Enciso, P. (2007). Reframing history in sociocultural theories: Toward an expansive vision. In Lewis, Enciso, \& Moje (Eds.). Reframing Sociocultural Research on Literacy: Identity, Agency, and Power. Mahwah, NJ: Lawrence Erlbaum Associates. 
Fitzgibbons, S. A., \& Tilley, C. L. (1999, November 10-14, 1999). Images of poverty in contemporary realistic fiction for youth: Preliminary results of a content analysis using a social psychological conceptual framework. Paper presented at the Third International Forum on Research in School Librarianship, annual Conference of the International Association of School Librarianship, Birmingham, AL.

Gay, G. (2010). Culturally responsive teaching: Theory, research, and practice (2nd ed.). New York: Teachers College Press.

Gilens, M. (2009). Why Americans hate welfare: Race, media, and the politics of antipoverty policy. Chicago, IL: University of Chicago Press.

Giroux, H. (2014). "Neoliberalism and the Machinery of Disposability," Tuesday, 08 April 2014 accessed August 19, 2015 at http://www.truthout.org/opinion/item/22958-neoliberalism-and-the-machinery-of-disposability

Goodman, J. M. (1985). From lemonade stands to Wall Street: Children's books' messages about the economy. Interracial Books for Children Bulletin, 16(2/3), 49.

Goodson, L. A. (2004). Protagonists in young adult literature and their reflection of society. (Doctoral dissertation, Kansas State University, 2004). ProQuest, UMI Dissertations Publishing, 3132165.

Gorski, P. (2008). The myth of the culture of poverty. Educational Leadership, 65(7), 3236.

Gyamfi, P., Brooks-Gunn, J., \& Jackson, A.P. (2001). Associations between employment and financial and parental stress in low-income single Black mothers. Women and Health. 32(1/2), 119-135.

Haberman, M. (1991/2010). Pedagogy of poverty versus good teaching. Phi Delta Kappan, 92(2), 81-87.

Hancock, C., \& Scherff, L. (2010). Who will stay and who will leave?: Predicting secondary English language arts teacher attrition. Journal of Teacher Education, 61(4), 328-338.

Harmon, M. Skate. (2007). New York: Laurel-Leaf.

Hill, C. (2011). Poverty through the lens of the Make Lemonade Trilogy. Signal, 34(52), 31-36. 
Hobbs, W. (2007). Crossing the wire. New York: HarperCollins.

Housing Assistance Council. (June 2012.) Poverty in rural America. Retrieved from: http://www.ruralhome.org/storage/research_notes/rrn_poverty.pdf

Hudson, C.G. (2005). Socioeconomic status and mental illness: Tests of the social causation and selection hypotheses. American Journal of Orthopsychiatry, 75, $3-18$.

Hughes, J. A. (2010) What teacher preparation programs can do to better prepare teachers to meet the challenges of educating students living in poverty Action in Teacher Education, 32:1, 54-64.

Jennings, T. (2007). Addressing diversity in U.S. teacher preparation programs: A survey of elementary and secondary programs' priorities and challenges from across the United States of America. Teaching and Teacher Education, 23 (8), 1258-1271.

Jensen, E. (2009). Teaching with poverty in mind: What being poor does to kids' brains and what schools can do about it. Alexandria, VA: Association for Supervision and Curriculum Development.

Jones, S. (2008). Grass houses: Representations and reinventions of social class through children's literature. Journal of Language and Literacy Education, 4(2), 40-58.

Kelley, J.E., \& Darragh, J.J. (2011). Depictions and gaps: Portrayal of U.S. poverty in realistic fiction children's picture books. Reading Horizons, 50(4), 263-282.

Kelley, J. E., Rosenberger, C., \& Botelho, M. J. (2005). Recurring themes about poverty in realistic fiction picture books. The Dragon Lode, 24(1), 25-30.

Lamme, L. L. (2000). Images of poverty in picture books with international settings. The New Advocate, 13(4), 347-364.

Lewis, C., Enciso, P., \& Moje, E.B. (2007a). Reframing sociocultural research on literacy: Identity, agency, and power. Mahwah, NJ: Lawrence Erlbaum Associates.

March of Dimes: Pregnancy and Newborn Health Education Center. (2012). Retrieved from: http://www.marchofdimes.com/downloads/teenagepregnancynodate.pdf

McDonald, J. (2002). Chill wind. New York: Farrar, Straus and Giroux. 
Murphy, M. and Ribarsky, E. (2013). Activities for teaching gender and sexuality in the university classroom. Lanham, MD: Rowman \& Littlefield.

Nilsen, A. P., and K. L. Donelson. (2009). Literature for today's young adults. Boston: Pearson.

Ortner, S. (1991). Reading America: Preliminary notes on class and culture. In Recapturing Anthropology. Santa Fe, NM: School of American Research Press.

Overstreet, D. W. (2001). Organize!: A look at labor history in young adult books. The Alan Review, 29(1), 60-66.

Payne, R. (2005). A framework for understanding poverty ( $4^{\text {th }}$ ed.). Highlands, TX: A-ha. Pearson, M.E. (2005). A room on Lorelei St. New York: Henry Holt.

Petrone, R., \& Lewis, M. A. (2012). Deficits, therapists, and a desire to distance: Secondary English preservice teachers' reasoning about their future students. English Education, 44 (3), 254-287.

Petrone, R., Sarigianides, S.T. \& Lewis, M.A. (2015). The youth lens: Analyzing adolescents/ce in literary texts. Journal of Literacy Research, 64(4), 506-533.

Plummer, B. (2010). Crime conundrum. The New Republic. Retrieved from: http://www.newrepublic.com/article/80316/relationship-poverty-crime-rateseconomic-conditions

Pollock, M., Deckman, S. Mira, M. and Shalaby, C. (2010). "But what can I do?”: Three necessary tensions in teaching teachers about race. Journal of Teacher Education, 61(3), 211-224.

Probst, R. (2004). Response \& analysis: Teaching literature in secondary school. Portsmouth, NH: Heinemann.

Rosenblatt, L.M. (1938). Literature as exploration. NY: D. Appleton-Century.

Rural Poverty Research Institute. (2013). Retrieved from: http://www.rupri.org/povhumservices.php

Sarigianides, S. T. (2012). Tensions in teaching adolescents/ce: Analyzing resistances in a young adult literature course. Journal of Adult \& Adolescent Literacy, 56 (3), 222-230.

Stephens, J. (2007). Young adult: A book by any other name... Defining the genre. The ALAN Review, 35(1), 34-42. 
U.S. Census Bureau: Social, Economic, and Housing Statistics Division: Poverty. (2013). Retrieved from: http://www.census.gov/hhes/www/poverty/links/

U.S. Department of Health and Human Services (July 2015). 2015 Poverty guidelines. Retrieved from: http://aspe.hhs.gov/poverty/15poverty.cfm

U.S. Department of Health and Human Services (August 2013). Trends in teen pregnancy and child bearing. Retrieved from: http://www.hhs.gov/ash/oah/adolescent-health-topics/reproductive-health/teenpregnancy/trends.html

Vanderstaay, S. (1992). Young-adult literature: A writer strikes the genre. The English Journal, 81(4), 48-52.

Vygotsky, L. (1993). The collected works of L.S. Vygotsky. NY: Plenum Press.

Why it matters (2010). Teen pregnancy. Poverty, and income disparity. Retrieved from: http://www.thenationalcampaign.org/why-it-matters/pdf/poverty.pdf

Wolff, V.E. (1993/2006). Make lemonade. New York, NY: Henry Holt and Company.

Wolff, V.E. (2001). True believer. New York, NY: Antheneum Books for Younger Readers.

Wolff, V.E. (2009). This full house. New York, NY: Harper Teens. 
Appendix A

Percentage of Children under 18 living in Poverty in the U.S., 2010 Compared to the Novels

\begin{tabular}{|l|l|l|}
\hline Category & $\begin{array}{l}\text { Percent } \\
\text { in the } \\
\text { U.S. } \\
\mathbf{2 0 1 0}\end{array}$ & $\begin{array}{l}\text { Percent } \\
\text { portrayed } \\
\text { in Novels }\end{array}$ \\
\hline White only, non-Hispanic & 12.4 & 53.5 \\
\hline Black & 38.2 & 19.7 \\
\hline Hispanic & 35.0 & 8.5 \\
\hline Asian & 13.6 & 0 \\
\hline Native American & 27.0 & 1.4 \\
\hline
\end{tabular}

(U.S. Census Bureau, 2013) 
Appendix B

Books Reviewed in this Study

\begin{tabular}{|c|c|c|c|c|c|c|}
\hline Title & State & Agency/Action & $\begin{array}{l}\text { Substance } \\
\text { Abuse }\end{array}$ & $\begin{array}{l}\text { Violence/ } \\
\text { Crime }\end{array}$ & $\begin{array}{l}\text { Mental } \\
\text { Health }\end{array}$ & $\begin{array}{l}\text { Teen } \\
\text { Pregnancy }\end{array}$ \\
\hline Jay & $\mathrm{IL}$ & Community & No & Yes & No & No \\
\hline $\begin{array}{l}\text { The Death of } \\
\text { Jayson Porter }\end{array}$ & FL & Family & Yes & Yes & Yes & No \\
\hline $\begin{array}{l}\text { The Absolutely } \\
\text { True Diary of } \\
\text { a Part Time } \\
\text { Indian }\end{array}$ & WA & Individual & Yes & Yes & Yes & No \\
\hline Prom & PA & Individual, friends & No & Yes & No & Yes \\
\hline $\begin{array}{l}\text { Rule of the } \\
\text { Bone }\end{array}$ & MI & Individual, friends & Yes & Yes & Yes & No \\
\hline $\begin{array}{l}\text { Hope Was } \\
\text { Here }\end{array}$ & WI & Individual, family, friends & No & Yes & No & No \\
\hline $\begin{array}{l}\text { Lupita } \\
\text { Manana }\end{array}$ & CA & Individual & No & Yes & No & No \\
\hline Almost Home & $\mathrm{CA}$ & $\begin{array}{l}\text { Individual, friends, } \\
\text { community }\end{array}$ & Yes & Yes & Yes & No \\
\hline Tyrell & NY & Individual, systemic & Yes & Yes & No & Yes \\
\hline Bronxwood & NY & Individual & Yes & Yes & No & Yes \\
\hline $\begin{array}{l}\text { my lost and } \\
\text { found life }\end{array}$ & $\mathrm{CA}$ & Individual, family, friends & Yes & Yes & No & No \\
\hline $\begin{array}{l}\text { When I Am } \\
\text { Singing to You }\end{array}$ & IA & $\begin{array}{l}\text { Individual, friends, } \\
\text { community, systemic }\end{array}$ & Yes & Yes & Yes & Yes \\
\hline $\begin{array}{l}\text { Forgotten: } \\
\text { Seventeen and }\end{array}$ & OR & $\begin{array}{l}\text { Individual, friends, } \\
\text { community }\end{array}$ & Yes & Yes & Yes & No \\
\hline
\end{tabular}




\begin{tabular}{|c|c|c|c|c|c|c|}
\hline Homeless & & & & & & \\
\hline Born in Sin & GA & $\begin{array}{l}\text { Individual, family, friends, } \\
\text { community }\end{array}$ & Yes & Yes & Yes & Yes \\
\hline Shelter & WA & Individual, systemic & Yes & No & Yes & Yes \\
\hline $\begin{array}{l}\text { Don't Breathe } \\
\text { A Word }\end{array}$ & WA & Individual, friends & Yes & Yes & Yes & No \\
\hline Ball Don't Lie & $\mathrm{CA}$ & Individual & Yes & Yes & Yes & Yes \\
\hline $\begin{array}{l}\text { Mexican } \\
\text { White Boy }\end{array}$ & $\mathrm{CA}$ & Individual, friends, family & Yes & Yes & No & Yes \\
\hline $\begin{array}{l}\text { Forged By } \\
\text { Fire }\end{array}$ & NY & None & Yes & Yes & Yes & No \\
\hline Runner & WA & Individual, systemic & Yes & Yes & Yes & No \\
\hline $\begin{array}{l}\text { Begging for } \\
\text { change }\end{array}$ & Unspecified & Individual, family, friends & Yes & Yes & Yes & No \\
\hline Title & State & Agency/Action & $\begin{array}{l}\text { Substance } \\
\text { Abuse }\end{array}$ & $\begin{array}{l}\text { Violence/ } \\
\text { Crime }\end{array}$ & $\begin{array}{l}\text { Mental } \\
\text { Health }\end{array}$ & $\begin{array}{l}\text { Teen } \\
\text { Pregnancy }\end{array}$ \\
\hline $\begin{array}{l}\text { Money } \\
\text { Hungry }\end{array}$ & Unspecified & Individual, friends & No & Yes & No & No \\
\hline $\begin{array}{l}\text { Keesha's } \\
\text { House }\end{array}$ & Unspecified & $\begin{array}{l}\text { Individual, family, friends, } \\
\text { community }\end{array}$ & Yes & Yes & Yes & Yes \\
\hline $\begin{array}{l}\text { Fat Kid Rules } \\
\text { the World }\end{array}$ & NY & Family, friends & Yes & Yes & Yes & No \\
\hline Saint Iggy & NY & Individual, family, friends & Yes & Yes & Yes & No \\
\hline $\begin{array}{l}\text { Summer } \\
\text { Sanctuary }\end{array}$ & $\begin{array}{l}\text { Unspecified } \\
\text { suburbs }\end{array}$ & Individual, family, friends & No & Yes & No & No \\
\hline $\begin{array}{l}\text { Ten Mile } \\
\text { River }\end{array}$ & NY & None & Yes & Yes & No & No \\
\hline $\begin{array}{l}\text { Bronx } \\
\text { Masquerade }\end{array}$ & NY & Community, systemic & No & Yes & No & No \\
\hline The & $\mathrm{CO}$ & Individual, community & No & Yes & Yes & No \\
\hline
\end{tabular}




\begin{tabular}{|c|c|c|c|c|c|c|}
\hline $\begin{array}{l}\text { Annunciation } \\
\text { of Francesca } \\
\text { Dunn }\end{array}$ & & & & & & \\
\hline Skate & WA & Individual, systemic & Yes & Yes, & Yes & No \\
\hline $\begin{array}{l}\text { crash boom } \\
\text { love }\end{array}$ & $\mathrm{CA}$ & $\begin{array}{l}\text { Individual, family, } \\
\text { community }\end{array}$ & Yes & Yes & No & No \\
\hline $\begin{array}{l}\text { Crossing the } \\
\text { Wire }\end{array}$ & $\mathrm{AZ}$ & Individual, family & No & Yes & No & No \\
\hline Tricks & NV & $\begin{array}{l}\text { Individual, friends, } \\
\text { community }\end{array}$ & Yes & Yes & Yes & Yes \\
\hline $\begin{array}{l}\text { Becoming } \\
\text { Chloe }\end{array}$ & NY & $\begin{array}{l}\text { Individual, family, friends, } \\
\text { community, strangers, } \\
\text { systemic }\end{array}$ & No & Yes & Yes & No \\
\hline $\begin{array}{l}\text { Tomorrow } \\
\text { Maybe }\end{array}$ & NY & None & Yes & Yes & Yes & No \\
\hline $\begin{array}{l}\text { Soul Moon } \\
\text { Soup }\end{array}$ & $\begin{array}{l}\text { Unspecified, } \\
\text { inner city }\end{array}$ & Family & Yes & Yes & No & Yes \\
\hline $\begin{array}{l}\text { Max and } \\
\text { Menna }\end{array}$ & $\mathrm{AL}$ & $\begin{array}{l}\text { Individual, family, } \\
\text { community, systemic }\end{array}$ & Yes & Yes & Yes & No \\
\hline $\begin{array}{l}\text { The Blue } \\
\text { Mirror }\end{array}$ & NY & $\begin{array}{l}\text { Individual, friends, family, } \\
\text { community, systemic }\end{array}$ & Yes & Yes & Yes & Yes \\
\hline Switch & $\mathrm{MN}$ & family & No & Yes & No & Yes \\
\hline Harlem Hustle & NY & Individual, community & No & Yes & No & No \\
\hline Chill Wind & NY & Individual & Yes & No & No & Yes \\
\hline Off-Color & NY & Family, systemic & No & No & No & No \\
\hline Spellbound & $\mathrm{NY}$ & Family, systemic & No & Yes, & No & Yes \\
\hline Cashay & IL & Community, systemic & Yes & Yes & Yes & Yes \\
\hline Joseph & $\mathrm{SC}$ & Individual, family & Yes & Yes & Yes & No \\
\hline Title & State & Agency/Action & $\begin{array}{l}\text { Substance } \\
\text { Abuse }\end{array}$ & $\begin{array}{l}\text { Violence/ } \\
\text { Crime }\end{array}$ & $\begin{array}{l}\text { Mental } \\
\text { Health }\end{array}$ & $\begin{array}{l}\text { Teen } \\
\text { Pregnancy }\end{array}$ \\
\hline
\end{tabular}




\begin{tabular}{|c|c|c|c|c|c|c|}
\hline Dairy Queen & WI & Community & No & No & No & No \\
\hline $\begin{array}{l}\text { Front and } \\
\text { Center }\end{array}$ & WI & Individual, community & No & No & No & No \\
\hline $\begin{array}{l}\text { The Off } \\
\text { Season }\end{array}$ & WI & $\begin{array}{l}\text { Individual, family, } \\
\text { Community }\end{array}$ & No & No & No & No \\
\hline Street Love & NY & Individual & Yes & Yes & Yes & Yes \\
\hline Shine & $\mathrm{NC}$ & Individual & Yes & Yes & No & No \\
\hline $\begin{array}{l}\text { Faith, Hope, } \\
\text { and Ivy June }\end{array}$ & KY & $\begin{array}{l}\text { Friends, family, } \\
\text { community }\end{array}$ & No & No & No & No \\
\hline Patiently Alice & MD & Community & No & No & No & No \\
\hline $\begin{array}{l}\text { A Room on } \\
\text { Lorelei Street }\end{array}$ & TX & Individual & Yes & No & Yes & No \\
\hline $\begin{array}{l}\text { Sorta Like a } \\
\text { Rock Star }\end{array}$ & $\mathrm{NJ}$ & $\begin{array}{l}\text { Individual, family, friends, } \\
\text { community }\end{array}$ & Yes & Yes & Yes & No \\
\hline Punkzilla & OR & Individual & Yes & Yes & Yes & No \\
\hline 33 Snowfish & $\mathrm{IL}$ & Friends, a stranger & Yes & Yes & Yes & Yes \\
\hline Holes & TX & Friends & No & Yes & No & No \\
\hline Push & NY & Community, individual & Yes & Yes & Yes & Yes \\
\hline The Kid & NY & Individual, systemic & Yes & Yes & Yes & Yes \\
\hline Pool Boy & $\mathrm{CA}$ & Individual, family & No & Yes & No & No \\
\hline Homeboyz & $\mathrm{CA}$ & $\begin{array}{l}\text { Individual, family, } \\
\text { systemic }\end{array}$ & Yes & Yes, & Yes & Yes \\
\hline $\begin{array}{l}\text { The Last } \\
\text { Summer of the } \\
\text { Death } \\
\text { Warriors }\end{array}$ & NM & $\begin{array}{l}\text { Individual, family, friends, } \\
\text { community, systemic }\end{array}$ & No & Yes & Yes & No \\
\hline If I Grow Up & NY & $\begin{array}{l}\text { Individual, family, } \\
\text { community }\end{array}$ & Yes & Yes & Yes & Yes \\
\hline $\begin{array}{l}\text { Can't Get } \\
\text { There From }\end{array}$ & NY & Community & Yes & Yes & Yes & No \\
\hline
\end{tabular}




\begin{tabular}{|l|l|l|l|l|l|l|}
\hline Here & & & & & & \\
\hline Runaway & CA & $\begin{array}{l}\text { Individual, family, friends, } \\
\text { community, systemic }\end{array}$ & Yes & Yes & Yes & No \\
\hline $\begin{array}{l}\text { Salvage the } \\
\text { Bones }\end{array}$ & MS & Family, community & No & Yes & No & Yes \\
\hline Broken China & TX & Individual, family, friends & Yes & Yes & No & Yes \\
\hline True Believer & Unspecified & $\begin{array}{l}\text { Individual, family, } \\
\text { community, systemic }\end{array}$ & No & No & No & Yes \\
\hline $\begin{array}{l}\text { This Full } \\
\text { House }\end{array}$ & Unspecified & $\begin{array}{l}\text { Individual, family, } \\
\text { community, systemic }\end{array}$ & No & No & No & No \\
\hline $\begin{array}{l}\text { Miracle's Boys } \\
\text { Title }\end{array}$ & NY & $\begin{array}{l}\text { Individual, family } \\
\text { Agency/Action }\end{array}$ & $\begin{array}{l}\text { Substance } \\
\text { Abuse }\end{array}$ & $\begin{array}{l}\text { Violence/ } \\
\text { Crime }\end{array}$ & $\begin{array}{l}\text { Mental } \\
\text { Health }\end{array}$ & Peen \\
\hline $\begin{array}{l}\text { Ponders of } \\
\text { the World }\end{array}$ & $\begin{array}{l}\text { Unspecified } \\
\text { college town }\end{array}$ & $\begin{array}{l}\text { Individual, friends, } \\
\text { community }\end{array}$ & Yes & Yes & Yes & No \\
\hline
\end{tabular}

